City University of New York (CUNY)

CUNY Academic Works

Publications and Research

John Jay College of Criminal Justice

1986

\title{
Jaipongan: Indigenous Popular Music of West Java
}

Peter L. Manuel

CUNY Graduate Center

Randall Baier

\section{How does access to this work benefit you? Let us know!}

More information about this work at: https://academicworks.cuny.edu/jj_pubs/316

Discover additional works at: https://academicworks.cuny.edu

This work is made publicly available by the City University of New York (CUNY).

Contact: AcademicWorks@cuny.edu 


\section{JAIPONGAN: INDIGENOUS POPULAR MUSIC OF WEST JAVA by \\ Peter Manuel and Randall Baier}

The advent of mass media - particularly cassettes and films - in Indonesia has led to the flowering of two mass popular music forms, namely, dangdut and jaipongan. Kroncong, an older urban popular form, presents a mixture of Portuguese folksong style and Indonesian features; dangdut style, while in some respects an extension of the orkes melayu tradition, is heavily influenced by Hindi film songs and Western pop; only jaipongan is purely Indonesian - or more properly speaking, Sundanese - in origin and style. While kroncong and dangdut have $r \epsilon$ ceived some scholarly attention (Becker 1975, Heins 1975, Frederick 1982), jaipongan has received only passing reference in a few publications. An examination of jaipongan is well overdue, in view of the phenomenal popularity of the genre not only in its home, West Java (Sunda), but throughout greater Java. This article is a preliminary study aimed at introducing the genre to English-speaking readers.

Popular music genres in traditional societies may be local variants of Western pop, mixtures of the latter with regional styles, or, less often, purely indigenous forms. Genres in the latter category usually develop from professional entertainment traditions, like the Vietnamese vong co or Arab cabaret music, or from predominantly rural forms, as is the case with jaipongan. Jaipongan, devoid as it is of foreign influences, can be seen as one of many regional varieties of a "gong-chime" performance continuum found throughout much of Indonesia, characterized by such features as: use of an ensemble dominated by idiophones (especially metallophones and knobbed gongs); a texture of stratified polyphony, with lower-pitch instruments playing parts of lesser density, all parts being structured colotomically around time-cycles; improvisation on certain instruments; and use of a set of modes grouped into loose variants of two broad scale types, slendro (Sundanese: "salendro") and pelog.

\section{KETUK TILU}

Several "gong-chime" musical traditions exist in Sunda, from the classical krawitan played by a full gamelan ensemble to the smaller degung ensemble of perhaps half a dozen musicians, with or without pesinden (female singer). Unlike these forms, which traditionally enjoyed 
aristocratic patronage, jaipongan evolved from folk music - in particular, a traditional Sundanese musical entertainment form called ketuk tilu. (See Plate 1.) Ketuk tilu was archetypically performed in a village, as part of a ceremony related usually to a harvest ritual, or often to a circumcision or marriage. The ensemble consists of a solo female singer-dancer (ronggeng), accompanied by spike fiddle (rabab or, rarely, the Chinese erh-hu), three pot gongs (ketuk), a hanging gong, two iron plates (kecrek), and two or three barrel drums. (See Plates 2 and 3.) The ensemble was thus small enough to be carried from village to village; in contexts where other instruments like sarons or kempul might be available (as, for example, in the modern recording studio), they might be freely added. (See Plate 4.)

The large hanging gong, and the smaller gongs kempul and ketuk serve colotomic functions, punctuating the timecycles at regular fixed intervals. The several ketuk play a standardized three-pitch figure (high - low - mediumlow) from which the name ketuk tilu - "three ketuk" derives. The spike fiddle may anticipate, imitate, or generally support the singer in a loosely heterophonic manner, or it may solo freely when the singer is silent. All the musicians, and especially the drummer, freely supplement the texture with rhythmic cries and yells (senggak), often in interlocking hocket style. The most important roles are those of the drummer and the singerdancer. The drummer plays in a far more aggressive and assertive style than in most other Javanese and Sundanese ensembles, commanding particular attention just before the large gong stroke by playing a loud, variable cadential figure. The ronggeng, however, remains the central figure, carrying the vocal melody while dancing at the same time. The lively interplay between the drummer and the ronggeng is one of the more distinctive features of ketuk tilu, and one which has carried over into jaipongan. Typically, a male in the audience will dance with the ronggeng, circling her gracefully without touching, in a dance style whose vocabulary of gestures and postures derives in part from the traditional martial art pencak silat. The dance, like the music, is structured around the gong cycles, in which tension is built up to be dispelled at the large gong stroke; often, just before the gong, the dancers, facing each other, will gracefully jerk their heads toward each other.

Ketuk tilu thus accompanies a social dance, although the female solo dancer is traditionally a professional, 
who is often assumed to be a prostitute. The institution of the ronggeng singer-dancer-prostitute is not, of course, unique to ketuk tilu, but is found in various other entertainment contexts in Java and Sunda, including the Sundanese tayuban, which is associated with more aristocratic patronage than the rustic ketuk tilu. Sutton has discussed some of the singer-dancer traditions in Java, noting how they have been important precursors of the predominance currently (and not previously) given to solo female singers in the context of Javanese gamelan (Sutton 1984a); it is clear that the prominence (f the ketuk tilu ronggeng role has carried over into jaipongan, divested of its disrepute. Jaipongan cassettes invariably advertise the singer's name above that of the accompanying musicians, and the covers feature alluring color photos of the singer. Accordingly, the singer is given greatest prominence in the recording.

The relatively recent and unprecedented rise to prominence of the pesinden in Javanese gamelan parallels the rise of a pesinden-centered genre like jaipongan, and the two phenomena seem to be related to broader socioeconomic factors. The market demand for solo "superstars" is an obvious impetus, but this itself must be seen in the context of the changes in Indonesian social economy. Traditionally, as Heins (1980:178) has noted, "Gamelan music is performed as a group effort in which there is no place for stardom," and this communal approach to musicmaking can be seen as a natural reflection of the traditional village economy in which collective endeavors played a large role. With the advent of free-market capitalism in this century, stressing the role of the individual as the primary socio-economic unit, it is perhaps not entirely surprising that new popular forms like jaipongan and dangdut are more individualistic and "star"-oriented, even if, as is the case with jaipongan, there may be a traditional ronggeng-centered precedent.

Traditionally, "respectable" women do not participate in ketuk tilu dancing, even with their husbands, although this convention has changed somewhat in modern ketuk tilu, not to mention jaipongan.

Ketuk tilu songs, following a free-rhythmic introduction, are structured sectionally, juxtaposing segments of short gong-cycles (about 10 seconds) with those of longer gong-cycles (about 30 seconds), each seciton having a characteristic sequence of dance steps associated with it. As in many older Javanese musical 
genres, poetic meter corresponds with gong and melody structure.

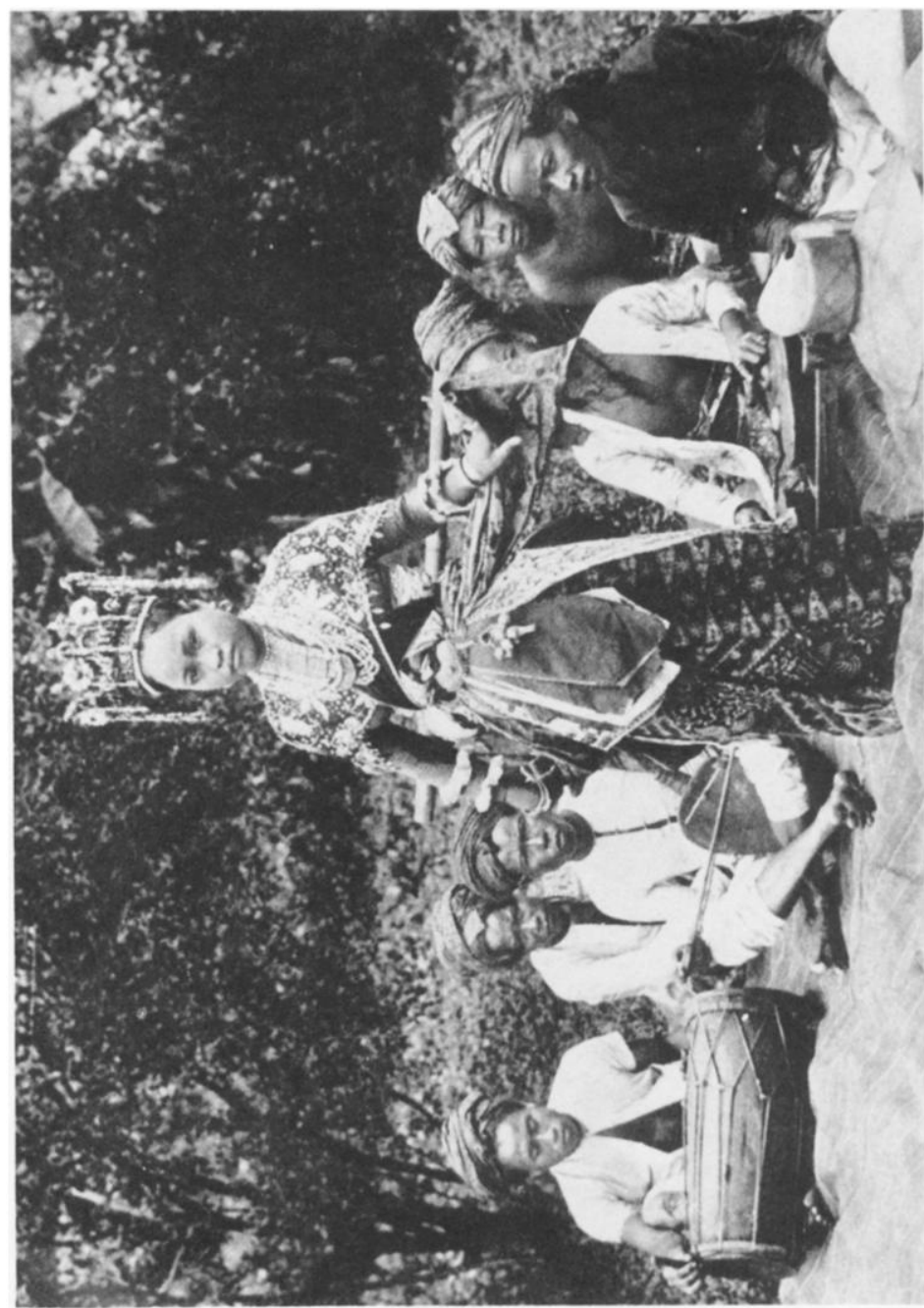

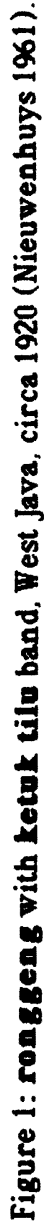




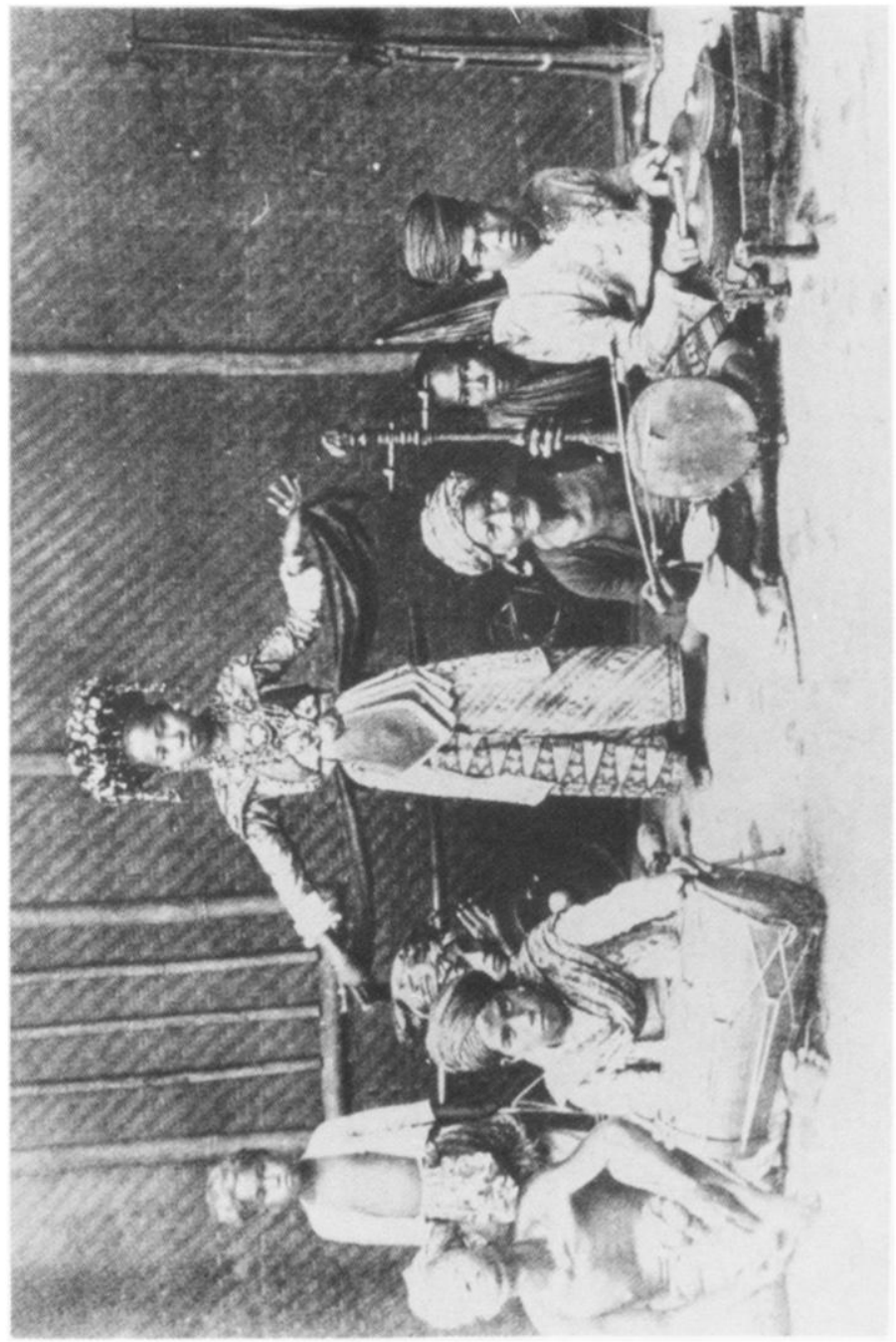

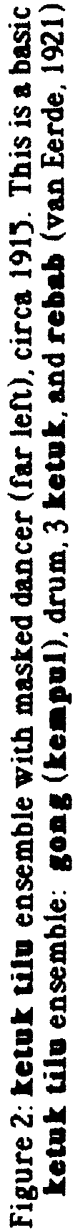




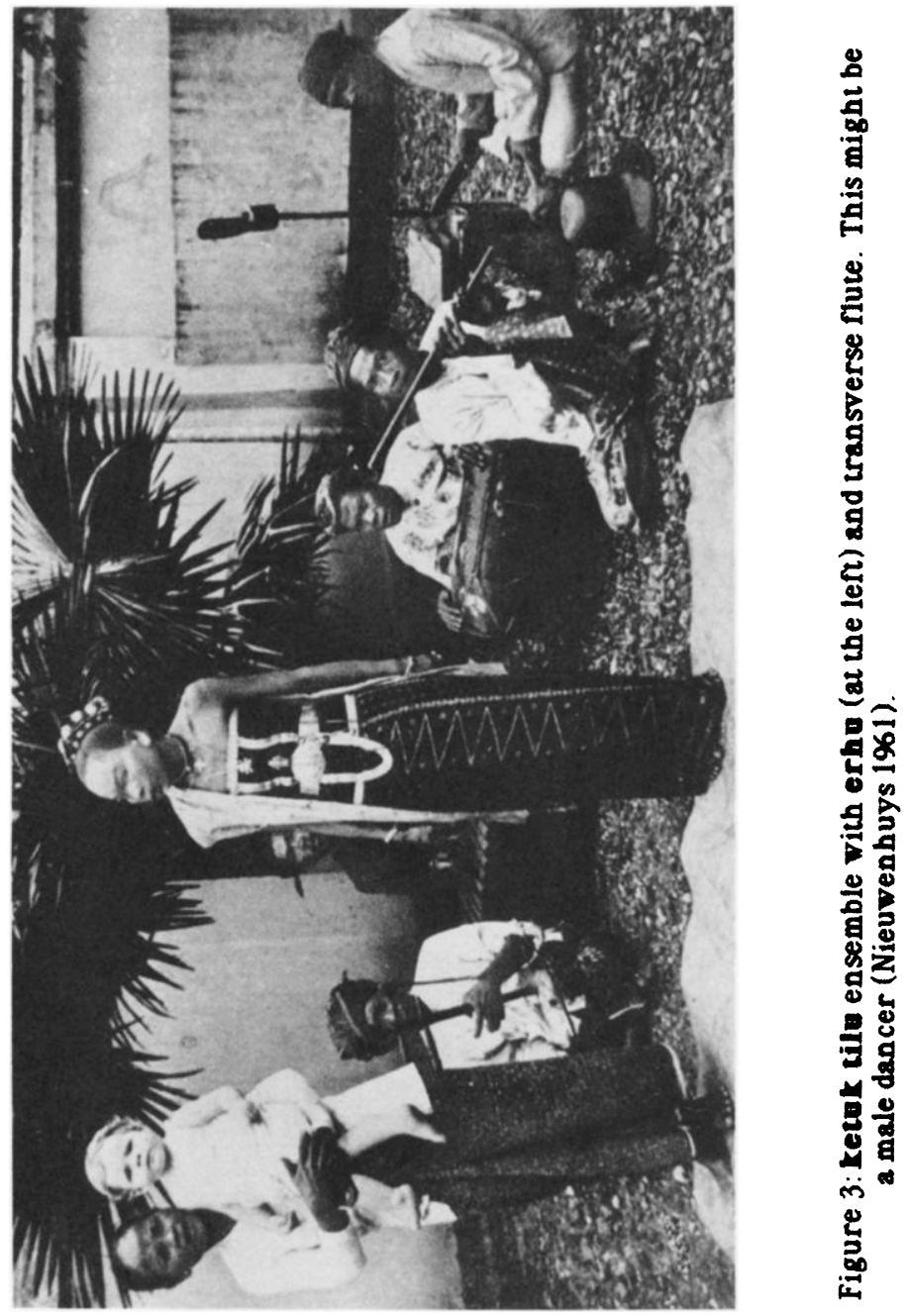



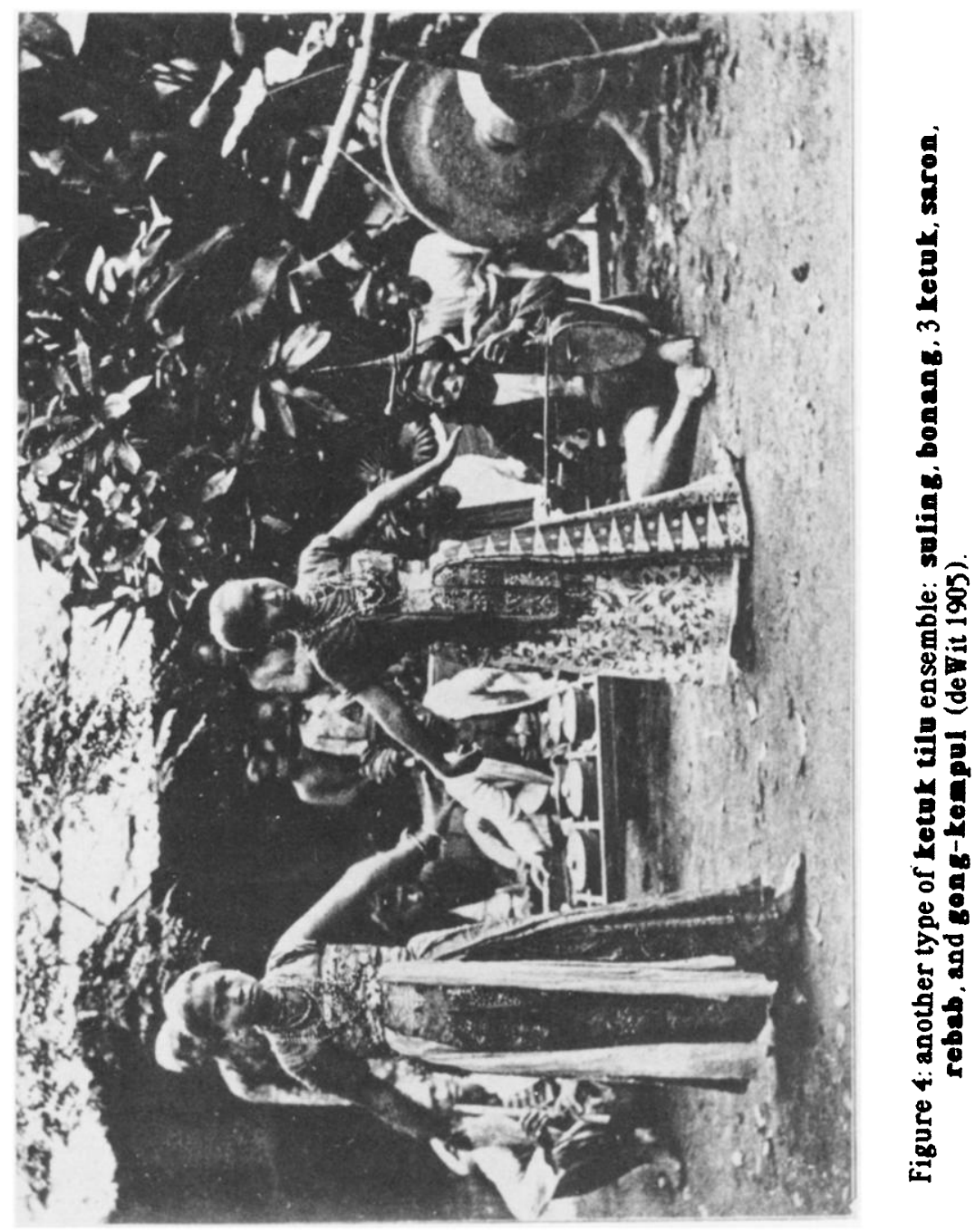

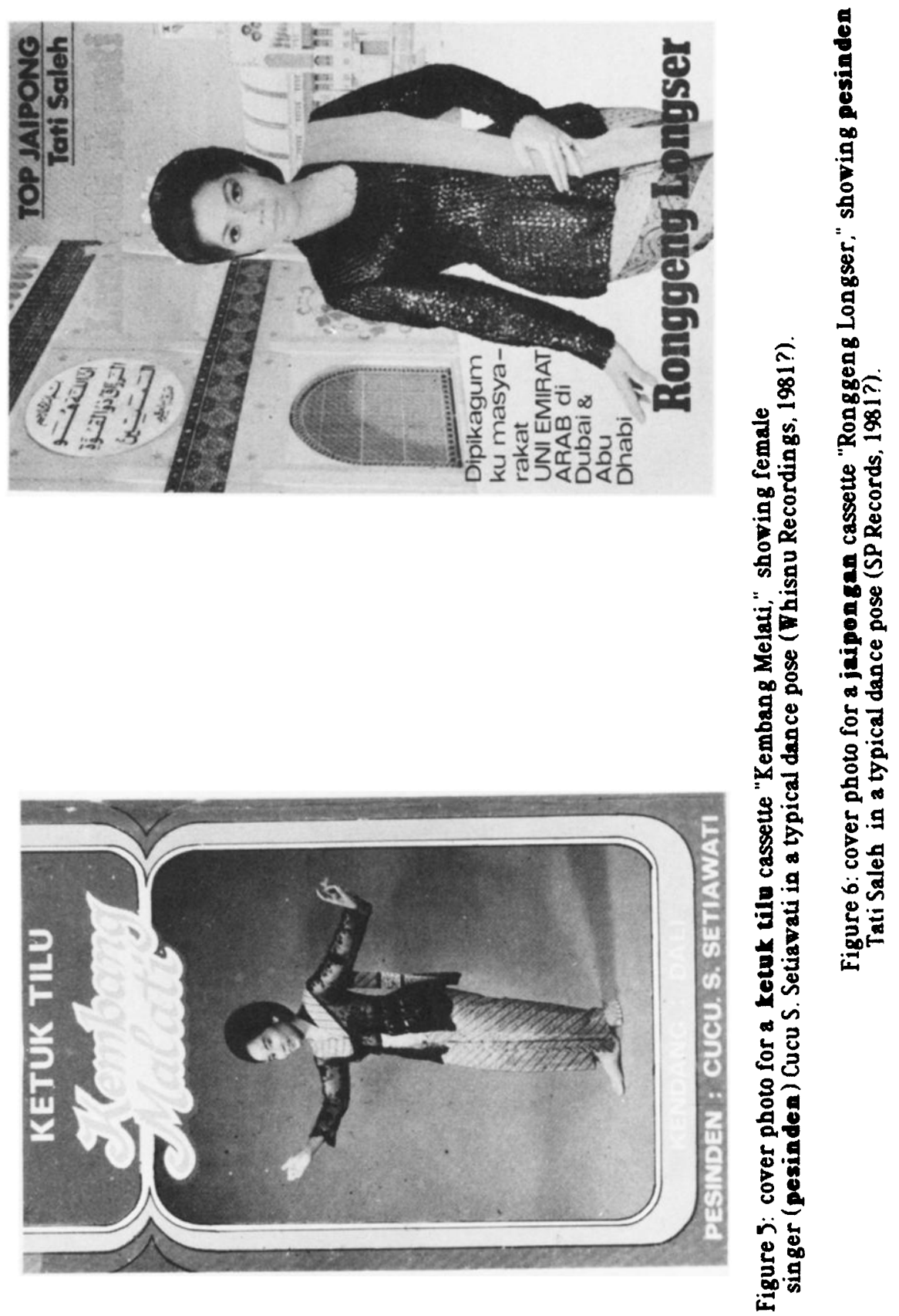
The spread of ketuk tilu beyond sunda has been limited by the use of the Sundanese language in its texts, and, to some extent, its rustic and crude image, deriving especially from the ill repute of the ronggeng. In the late 1970s, jaipongan began to evolve as a more slick and expanded version of ketuk tilu, largely free of any association with prostitution. Jaipongan is also less strictly associated with rustic ceremonial functions like harvest rituals, although performances of the genre are particularly common in the Rayagung festival month, in festivals around Independence Day (August 17), as well as in connection with circumcisions and marriages. While most performances may still be loosely related to some life-cycle function, they now have the character of secular social functions, attended by young and old, primarily for entertainment and socializing.

Public performances of jaipongan are now extremely frequent, not only in Bandung but also in smaller provincial centers. Nevertheless, the rise of jaipongan is directly linked to the advent of the mass media in Java. These include the cinema, state-controlled radio, and especially cassettes. In the l970s, oil wealth and the relatively unrestricted import of cheap tape and recorders led to an extraordinary boom of the Indonesian cassette industry. (See Plates 5 and 6.) Sutton (1984b) has examined the rise of this industry and its relation to Javanese art musics and Banyumas rural music. Sutton notes how, while the broad marketing of cassettes makes "Great Tradition" styles (e.g., central Javanese court musics) available throughout Java, this penetration of local markets has not necessarily led to a musical homogenization or a weakening of regional styles. On the contrary, local cassette industries in some respects have promoted regional styles, because, rather than being large national corporations, they are regional "backyard" enterprises that record, dub, and market local music primarily for local consumption. It is clear from Sutton's description that whatever may be the role of music industries elsewhere, the Javanese cassette industry thus actually promotes regional music and musics of the economic lower class rather than superimposing any one particular set of styles on a diverse audience. It is also clear that the ability of the local, grass-roots traditions to resist media domination by corporateproduced pop derives from local control of the means of (music) production, in the sense that the capital 
investment required to start and operate a backyard cassette industry may be relatively small. In the case of a bootleg cassette industry selling dubs for one-half to two-thirds the price of the originals, the capital investment - both on the part of the consumer and the producer - is even smaller. Many of the small studios are owned by Chinese Indonesians, but these are clearly still far more responsive to immediate local tastes than, for example, the Hindi film music industry, in which a handful of corporate Bombay studios produces music to be passively accepted or rejected by an impersonal mass audience numbering in the hundreds of millions.

Jaipongan rode the crest of the cassette boom, extending its market throughout Java, in spite of the fact that performing groups remain based in Sunda. While live concerts of jaipongan occur regularly in sunda, the media have been in several aspects integral to its growth. First of all, in the realm of media-based entertainment listening (e.g., on the radio and cassettes), jaipongan is currently preferred to any other sundanese genre, being rivalled only by dangdut. Whether wafting out from kampung shacks or booming from a cafe's boom-box, jaipongan is ubiquitous, and the role of the media in spreading it is obvious. Secondly, media dissemination has exerted prodigious influence on style, since competing groups - and especially drummers - take active interest in the innovations and musics of other groups (while generally attempting to retain their own individual styles).

Finally, jaipongan dance styles are generally taught with cassette rather than live accompaniment. The rise of jaipongan social dancing has, indeed, led to the flowering of innumerable private dance instruction schools, where teenagers attend jaipongan classes, in much the same way Westerners amuse themselves learning the foxtrot and the chachacha at an Arthur Murray studio. Thus, the traditional absence of female social dancing in sunda - or rather, its confinement to the ronggeng - is quickly being altered by the rise of jaipongan and the dance schools related to it; moreover, as we have seen, both of these institutions are integrally linked to the media.

The male jaipongan dance style is less acrobatic and martial than the male ketuk tilu style, and is regarded as simple by afficionados of the latter. The female jaipongan dance, however, is considerably more active than that of the ketuk tilu ronggeng, whose main choreographic 
role is to coyly receive or parry the male's stylized advances. Moreover, the jaipongan style has developed considerable subtlety and refinement, and $a$ kind of sophisticated polish less evident in the rustic ketuk tilu.

\section{JAIPONGAN STYLE AND FORM}

We may now turn to a musical analysis of jaipongan, and its evolutionary relationship to ketuk tilu. The development of jaipongan from ketuk tilu in the late 1970s is associated in particular with Gugum Gumbira and the group "Jugala." The genre soon spread to the extent that it would be difficult to select any particular groups as current leaders.

The instrumentation of jaipongan resembles that of ketuk tilu, with the difference that the drummer may use up to six drums (rather than two), and the idiophonic accompaniment may include a few saron or a degung (an Lshaped row of gong-chimes), and often a gambang (xylophone). The kecrek, spike fiddle, kempul, and gong are retained, performing similar functions as in ketuk tilu. Again, instrumentation may vary somewhat, depending on the group or on the availability of instruments.

The sectional formal structure of ketuk tilu is one feature that has not been carried over to jaipongan; typically, a jaipongan piece opens with a few gong cycles (often in a different tempo from the rest of the piece) during which the fiddle player improvises over the idiophone and drum accompaniment; the vocalist then enters, usually singing four gongan (gong cycles) consecutively, then allowing the fiddler to improvise for two gongan. After alternating in this fashion for several minutes, the piece ends with a deceleration leading to the final gong.

While jaipongan lacks the additive formal structure of ketuk tilu, it has adopted certain aspects of the internal ketuk tilu colotomic structure; notable among these are the kempul patterns, whose stroke density characteristically doubles or quadruples as the final gong approaches, as shown below ( $\mathrm{p}=$ kempul) and in example 2:
12
$\begin{array}{lll}\mathrm{p} & & \mathrm{p} \\ 2 & 3 & 4\end{array}$
$5 \quad \frac{p}{6}$
$p$
8
p
$11 \quad \frac{p}{12}$
13
$p \mathrm{p} p$ (gong) 
Jaipongan drumming, while clearly an extension of ketuk tilu style, is considerably more flamboyant and virtuosic, and accordingly, cassettes generally feature the drummer's name immediately below that of the singer. As in ketuk tilu, the drummer performs lively improvisations throughout, building up tension which culminates and is released at the gong stroke. A distinctively sundanese feature is the variation of the pitch of the main drum, whose head tension is governed by the foot of the drummer. Another unique characteristic is the practice of concluding a drum cadential figure immediately before the gong, thus climaxing on the upbeat and allowing the downbeat to be stressed only by the gong, and by the listener's own learned perception of the inherent importance of that beat. Two typical examples of these cadences are shown here:

Example 1:

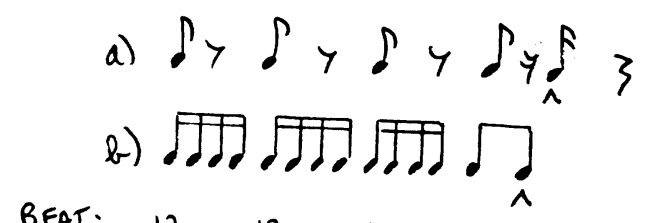

BEAT: $12 \quad 13 \quad 14$

$15 \quad 16$

Often, drum patterns take the form of similar but subsidiary cadences on beats four, eight, and twelve, climaxing in the final cadence on sixteen, as in example 2 below.

\footnotetext{
Jaipongan melodies invariably consist of four lines, set within a single gong-cycle. The text is set strophically, and the rhythmic setting of the quatrain usually loosely resembles that of example 2 .

(Note on example 2: the third line represents a composite performed on two interlocking sarons; the pitches were occasionally unclear.)
} 
Example 2:

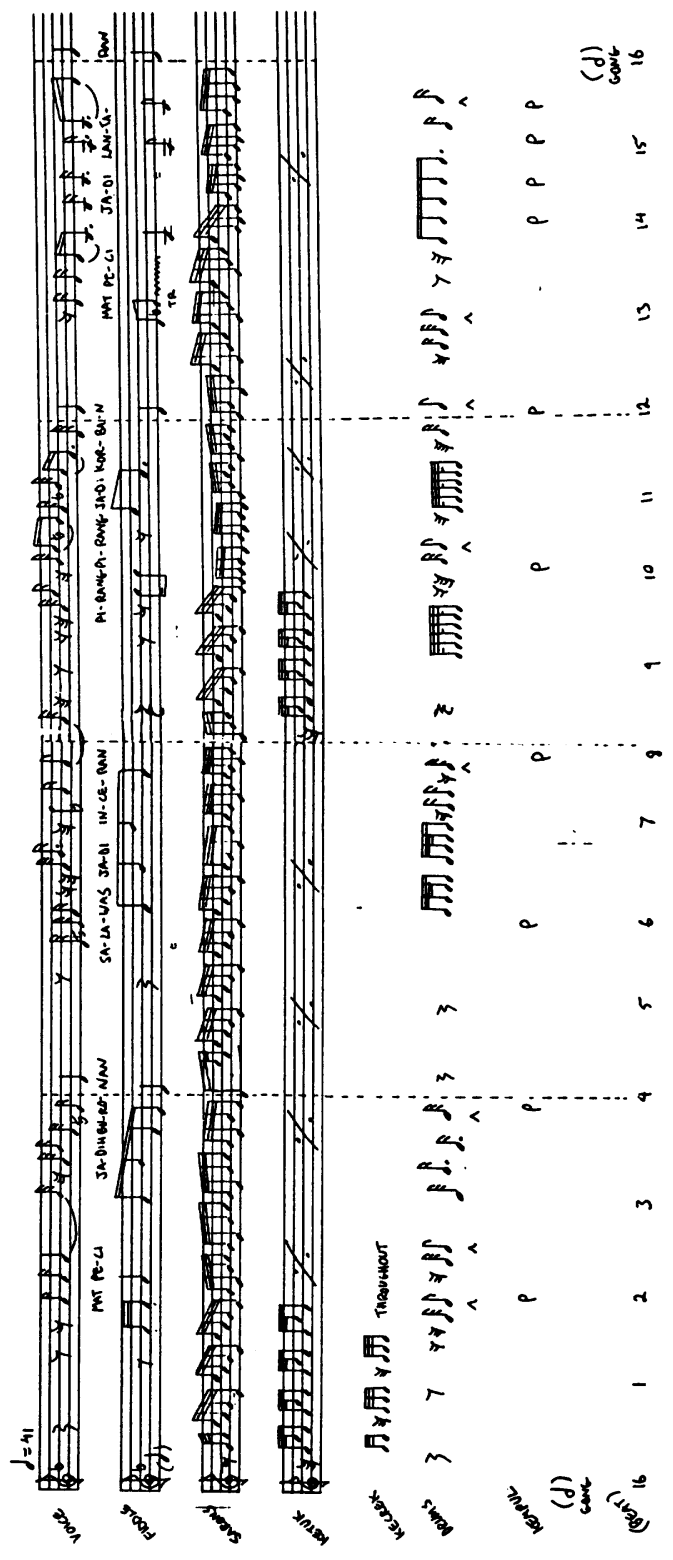

103 
The melodies themselves are set either to heptatonic madenda (madenda is a Sundanese variant of pelog), or, less often, to pentatonic salendro skeletal tunings. Precise intonation of these scales varies considerably; the pelog configuration may be vaguely approximated as : D $E^{b} F$ (G) $A B^{b}$ (C), with $D$ generally functioning as what Westerners might call a tonic. That pitch, however, may not always function as a finalis, nor is it counted as primary in the sundanese numerical designations (which proceed from high to low). In madenda, the second scalar degree would be closer to E natural.

Salendro intonation is even less consistent, and the sense of a "tonic" much weaker; the configuration, however, usually approximates the familiar anhemitonic "black-key" pentatonic scale. Within this broad framework, however, Sundanese, and especially jaipongan treatment of mode is very distinctive and merits detailed study. (Harrel [1975] discusses in some detail the intervallic relationships in sundanese mode, but some aspects of his treatment - including the concepts of 10-, 15-, and 17-pitch salendro - may be more reflective of the theoretical ideas of his particular informants than of most Sundanese practicing musicians.)

Since jaipongan melodies are sometimes stereotypical, much of the charm and expressiveness of the singing comes from the introduction (whether improvised or pre-composed) of extraneous notes, whether functioning as alternate scale degrees or establishing temporary modal modulations. often the melody may alternate between pelog (or madenda) and salendro, or seem to be a free combination of the two, as, for example, when the sixth degree of the madenda scale (here, B) is raised and the normally weak fourth degree is stressed. Intonation may be further obscured by the characteristic vibrato, used especially on the unstable second and sixth pelog degrees. The sundanese vibrato resembles Western operatic vibrato in its speed and range, but characteristically ends abruptly on the upper note of a trill, as in the following excerpt:

Example 3:

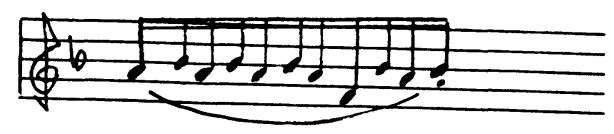


An interesting feature of jaipongan (and other Sundanese genres like ketuk tilu) is that while the vocal (and fiddle) melodies are usually in the pelog or madenda scales, the fixed-pitch idiophonic accompaniment is strictly in salendro. This combination of pelog and salendro contrasts with most Javanese gamelan traditions, where gamelans usually consist of paired instruments in the two tuning systems. However, it is encountered in a few lesser Indonesian genres, especially archaic ones that seem to represent fusions of discrete vocal and instrumental traditions. Jaipongan may be an instance of this sort of confluence, since sundanese gamelan, calung, and bamboo angklung ensembles are strictly salendro, while the predominant sundanese vocal genres pantun and tembang are mostly in pelog or madenda. This confluence may also represent an example of the sort of phenomenon described by Hoffman (1978), who, referring specifically to the combination of sustained, irregular vocal melodies and regular colotomic structures in Javanese serimpi and bedhaya, argues that the coincidence and combination of disparate "epistomologies" is a recurring feature in Javanese arts.

The apparent dissonance between the salendro idiophones and the pelog voice and fiddle is mitigated, first, by the frequent vibrato and microtonal alterations in the vocal line, and, more importantly, by the stressing of the common (or approximately common) notes in the two systems. The congruence between the two systems as used in Sunda is illustrated below (here taking $D$ as a pelog "tonic"; all pitches are approximate):

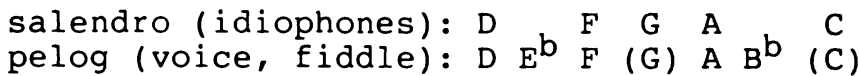

This juxtaposition of the two tunings is also evident in example 2 above.

\section{SONG REPERTOIRE}

The song repertoire of jaipongan is quite varied, and hence, jaipongan is better understood as a performance style than as a distinct body of compositions. In Sunda, as elsewhere in Java, compositions, or patokan - denoting skeletal melodic structures - may be performed in different styles and contexts; thus, for example, a patokan like "Wahed" might be played by an anklung group (dominated by shaken bamboo rattles), by a degung chamber ensemble, or by a full gamelan, with appropriate stylistic 
differences in each case. To some extent, however, one may distinguish between the song repertoires of the folk anklung and bamboo xylophone calung ensembles, and that of the more professional ketuk tilu, degung, and gamelan traditions. Jaipongan, in accordance with its origins in ketuk tilu, derives its repertoire mostly from the traditions of the latter group, although it may occasionally employ songs in the anklung/calung repertoire. Many jaipongan songs, like "Beruntuk," are associated specifically with ketuk tilu; others, like "Renggong Buyut," are songs existing throughout Java in regional varieties (Banyumas, Cirebon, etc.).

Much of the jaipongan repertoire, however, is not traditional, but consists of songs of recent origin (whether composed specifically for jaipongan style or not); such a song, for instance, is "Mat Peci" of example 2 , a lagu alit or "short song."

Subject matter of song texts varies in accordance with the diverse sources of the repertoire, encompassing amatory, moralistic, bawdy, topical, and even spiritual subjects (as in the traditional invocation "Kidung").

The text of "Mat Peci" is fairly representataive of the topical lagu alit category, and nicely illustrates certain aspects of jaipongan textual form and content.

Mat Peci penjahat ulung operasi di kota Bandung geus dimuat judul film najan jahat tapi kalem

Alat-nagara geus mati gugur di Pasa Kosambi nitis mangsana geus pasti gara-garana ku Mat Peci

Mat Peci jadi buronan salawas jadi inceran pirang-pirang jadi korban Mat Peci jadi lantaran.
Mat Peci ran his operation out of Bandung; such was his fame that a movie was made about him; even though he was a criminal, he was self-disciplined.

He killed a cop in Pasar Kosambi (a large market in Bandung); that cop was destined to die at the hands of Mat Peci.

He was the most wanted outlaw, was searched for desperately; everywhere police were getting killed, and Mat Peci became all the more infamous. 
Kudi tamatna carita

Mat Peci geus jadi mangsa

najan Mat Peci buraong

paeh ku hansip Tarongong.
We must end our story here; Mat Peci met his destiny; although feared by many, he ended up being done in by a local civil cop.

Extraneous calls are added freely throughout: "asjiiiiik" (loosely, "crazy!", i.e., with desire); "tobat" ("I give in!"), and "Mana tahan!" (a standard teasing by a prostitute, along the lines of "How can you resist?")

We may note, first of all, the typical formal organization of the verse in quatrains (each encompassed in one gong-cycle) in the rhyme-scheme aabbcc etc., each line having around eight syllables, as in most sundanese folk and popular verse.

The subject matter is particularly revealing of jaipongan's immersion in contemporary grassroots culture. Mat Peci was a Sundanese desperado who became well known for his criminal exploits in the 1970s, his renown culminating when a feature film was made about his life. Mat Peci stole only from the rich, and was often sheltered from the police by lower-class sympathizers and friends. He was believed by many to have magical powers, enabling him, for example, to disappear on occasion. As the song suggests, he was near the top of the "wanted" list and was sought - and feared - by all levels of the police. The text of this song, aside from noting his controlled and disciplined character, does not explicitly praise him as a Robin Hood or condemn him as an outlaw. What it does stress, however, is that he was ultimately captured not by top detectives or by an elaborate trap, but rather by a hansip - a menial, local civil policeman of the lowest rank, the sort which may be armed only with a nightstick. This fact, Mat Peci's folk reputation, and the song's references to the working class Tarogong neighborhood all reflect jaipongan's ties to contemporary grassroots culture.

\section{JAIPONGAN IN PERFORMANCE}

As mentioned above, public performances of jaipongan are most likely to occur in the Rayagung festival month, or in connection with a circumcision or wedding. Sometimes, however, they are held merely for their own entertainment value; moreover, there are now clubs in Bandung where one can dance to live jaipongan; a man may bring his wife or girlfriend, or he may dance with a 
"hostess" provided by the club (who should no longer be automatically assumed to be a prostitute). Jaipongan is also frequently performed by wayang ensembles before or in between acts of the dramatic presentation.

Outside of these contexts, the most typical setting for a jaipongan performance is a side street or alley, where a private host - for whatever special occasion will have a canopy-covered stage constructed, extending from his front porch into the alley. Invited guests sit near the performing ensemble on the porch, while neighbors and passers-by gather freely around the stage. Someone often a close friend of the host - performs the role of emcee, formally commencing the event in the late afternoon. He, the ensemble leader, or perhaps a hired imam, will lead an opening invocation, and then, perhaps after a few speeches by government bureaucrats, the music begins. For the first hour or so, the dancing is less participatory than a spectator event, with a conventional order of dancers appearing on stage. First, groups of a half-dozen or so young girls - perhaps as young as three years old - are led onstage to dance, facing the audience; then may follow two or three groups in sequence, each a few years older than the preceding group. Only when the teenagers' turn arrives do mixed couples commence dancing, and the event becomes progressively more open to free audience participation. Married couples may ascend the stage to dance, or single men may dance with women already onstage, frequently tipping the pesinden. The event, while encouraging and training young dancers and promoting a sophisticated popular art form, retains an atmosphere of merry enjoyment.

\section{CONCLUSIONS}

As we have mentioned, popular music forms emerging in traditional societies most often develop from professional entertainment traditions whose performers, and often patrons, are held in some sort of disrepute. Very often, these popular forms emerge among urban lumpen proletariats, as is the case, for example, with kroncong, dangdut, Greek rebetika, West Indian steel band music, reggae, and the tango. Jaipongan shares the somewhat disreputable origins of these genres, but differs from most modern popular music forms in that its origins were predominantly rural, and, perhaps more noticeably, in that it is totally indigenous in style. Unlike some of the forms mentioned above, there is no addition of electric guitar, or Western harmonies over a modal melodic 
conception. Jaipongan is thus one of the relatively few mass media-based pop musics that has resisted any Western or foreign influence. clearly, the rise of this genre illustrates the vitality of Sundanese culture; moreover, jaipongan's resistance of Westernization cannot be attributed to provincial unfamiliarity with Western musics, since the form coexists alongside the more acculturated kroncong and dangdut. Jaipongan is one of many felicitous illustrations of the fact that where control of the media is not excessively concentrated, the mass media, rather than obliterating regional traditions in a cultural "grey-out" (or "glitter-out"), may in fact promote the rise of vital new regional styles.

Jaipongan has become perhaps the only regional Indonesian genre sung in a regional language to achieve great popularity outside its place of origin. Top names like Tati Saleh, Dede Winingsih, Karawang, and Suwanda Group are now familiar to listeners throughout Java and Sumatra, and, moreover, the genre has spawned several hybrids, including reog-jaipong (using angklung), Chinese influenced "mandarin-jaipong," jaipongan-style renditions of TV pop tunes (see Tempo 1982), calung-jaipong, "jaipongan versi Banymas," and "jula-juli jaipongan" - the latter two being fusions with Banyumas and East Javanese styles, respectively (Sutton 1984b). While a few informants have opined that the jaipongan fad has already started to wane, these hybrids, and the evident cultural vitality of Sunda would seem to assure its cortinuation in some form.

\section{REFERENCES CITED}

Becker, Judith 1975

"Kroncong, Indonesian Popular Music." Asian Music 7 (1), pp. 14-19.

Eerde, Johan Christiaan Van

1921 De Volken van Nederlandsch-Indië.

Amsterdam: Elsevier.

$\rightarrow$ Frederick, William 1982

"Rhoma Irama and the Dangdut Style: Aspects of Contemporary Indonesian Popular Culture." Indonesia 34, pp. 102-130. 
Harrel, Max

1975

"Some Aspects of Sundanese Music."

Selected Reports in Ethnomusicology 2

(2), pp. 81-101.

$\rightarrow$ Heins, Ernst

1975

"Kroncong and Tanjidor: Two Cases of Urban Folk Music in Jakarta." Asian Music 7 (1), pp. 20-32.

1980

"Indonesia: II:2." The New Grove Dictionary of Music and Musicians. London: Macmillan Publishers. Vol. 9, pp. 173-179.

$\rightarrow$ Hoffman, Stanley 1978

"Epistemology and Music: A Javanese Example." Ethnomusicology 22 (1), pp. 69-88.

Nieuwenhuys, Robert 1961

Tempo Doeloe. Amsterdam: Em. Querido.

$\rightarrow$ Sutton, R. Anderson

$1984 a$

"Who is the Pesindhen? Notes on the Female Singing Tradition in Java." Indonesia 37, pp. 119-34.

$1984 \mathrm{~b}$

"Commercial Cassette Recordings of Traditional Music in Java: Implications for Scholars." Paper presented at the 1984 Annual Conference of the Society for Ethnomusicology, Los Angeles, CA.

Tempo (an Indonesian news weekly) 1982

"Blak-Ting-Pong. Mau Goyong?" (BlakTing-Pong. Want to Rock?). January 9, p. 60 .

Wit, Augusta de 1905

Java Facts and Fancies. The Hague: W.P. van Stockum.

Columbia University University of Wisconsin 